\title{
Implementasi nilai-nilai multikultural dalam pembelajaran pendidikan kewarganegaraan
}

\author{
Sukron Mazid *, Suharno Suharno \\ Pendidikan Pancasila dan Kewarganegaraan, Pascasarjana, Universitas Negeri Yogyakarta. \\ Jalan Majapahit No. 62, Mataram, Nusa Tenggara Barat 83115, Indonesia \\ moy.mazid99@gmail.com \\ * Corresponding Author
}

\section{ARTICLE INFO}

\section{Article History}

Received:

1 August 2016;

Accepted:

24 October 2019

\section{Keywords}

Implementasi nilai; Multikultural; Pembelajaran PKn; Kultur sekolah; Value implementation; Multicultural; Citizenship education learning

\begin{abstract}
ABSTRAK
Penelitian ini bertujuan untuk mengungkapkan 1.) Bagaimana implementasi; 2.) Faktor pendukung; 3.) Hambatan dalam implementasi nilai-nilai multikultural dalam pembelajaran PKn di MA Ali Maksum Krapyak Yogyakarta. Pendekatan penelitian menggunakan kualitatif. Penentuan subjek dengan purposive. Teknik pengumpulan data observasi, dokumentasi, wawancara. Keabsahan data diperoleh dengan teknik trianggulasi sumber. Teknik analisis dengan reduksi data, sajian data, dan penarikan simpulan. Hasil penelitian menunjukan bahwa implementasi dilakukan dengan dua tataran: a.) Konseptual melalui visi, misi, tujuan, sedangkan b.) Operasional melalui pertama perencanaan pembelajaran, kedua pelaksanaan pembelajaran melalui: 1.) Menanamkan nilai untuk bersikap toleransi, menghargai, demokrasi, keadilan, kesetaraan dan menghormati keragaman; 2.) Metode yang demokratis, kooperatif dan bervariasi; 3.) Materi yang diajarkan mengandung wawasan keragaman, persitiwa dan masalah sosial; 4.) Melatih peserta didik untuk memecahkan masalah-masalah sosial; dan 5.) Media pembelajaran dengan media yang bervariasi. Ketiga evaluasi pembelajaran. Faktor-fakor pendukung adalah peran kepala sekolah, peran guru, kurikulum sekolah, media pembelajaran, kegiatan dan program sekolah, iklim sekolah, dan peserta didik. Hambatan yaitu kurangnya kesiapan dan kesadaran peserta didik, kurangnya sarana dan prasarana, dan minimnya ruang untuk melakukan refleksi.
\end{abstract}

This research aims to reveal 1.) How the implementation; 2.) Factor supporting; 3.) Obstacles for the implementation of values multicultural in teaching Pkn in MA Ali Maksum Krapyak Yogyakarta. Approach the research uses qualitative. The determination of the subject with the purposive. Technique data collection observation, documentation, interview. The validity of data is collected to technique trianggulasi source. Technique analysis by reduction data, cereal offering data, and the withdrawal of drawing conclusions. The results of the study showed that the implementation of be done with two landscape a.) conceptual through vision, mission, the purpose and b.) operational through first planning learning. Second presentation weighting through; 1.) Imparting value to be tolerance, appreciate, democracy, justice, equality and respecting diversity; 2.) The method of democratic, cooperative and vary; 3.) The materials given containing insight diversity, 3 and a social issue; 4.) Train school tuition to tackle problems social; and 5.) The media teaching to the media varying. Third evaluation teaching. Supporting factor-factor is the role of the head school, the teacher, school curriculum, media teaching, activities and school program, climate school, and school tuition. Obstacles that is lack of readiness and awareness school tuition, lack of facilities and infrastructure, and inadequate room to make reflection.

This is an open access article under the CC-BY-SA license. 


\section{PENDAHULUAN}

Pendidikan merupakan bagian dari kegiatan berbangsa dan bernegara. Oleh sebab itu, pendidikan merupakan perwujudan dari cita-cita bangsa. Indonesia adalah salah satu negara multikultural terbesar di dunia, kebenaran dari pernyataan ini dapat dilihat dari kondisi sosio-kultural maupun geografis yang begitu beragam dan luas. Indonesia juga negara dengan kenyataan yang beragam, baik etnis, suku budaya maupun sisi kepercayaan. Mahfud (2014, p.8) mengemukakan bahwa secara riil, bangsa Indonesia memiliki keragaman bahasa, sosial, budaya, agama, aspirasi politik, serta kemampuan ekonomi. Ada beberapa indikator yang menunjukkan adanya penekanan semangat ke-ika-an dari pada semangat kebhinekaan dalam praktik pendidikan di Indonesia. Di antaranya terlihat pada. (1) terjadinya penyeragaman kurikulum dan metode pembelajaran, (2) terjadi sentralisasi dalam pengelolaan pendidikan, yang sarat dengan instruksi, petunjuk, dan pengarahan dari atas, sebagai akibat dari paradigma pendidikan sentralistik (top-down), dan (3) belum adanya proses menghargai dan mengakomodasi perbedaan dengan latar belakang peserta didik yang menyangkut budaya, etnik, bahasa dan agama (Zamroni, 2001, pp. 10-12).

Adha dan Yanzi $(2013$, p. 4) mengatakan bahwa pendidikan kewarganegaraan merupakan salah satu mata pelajaran yang memberikan pemahaman kehidupan sosial memiliki posisi strategis untuk mengembangkan kondisi pendidikan yang mencerminkan situasi masyarakat Indonesia yang multikultural. Tetapi kenyataanya dalam pembelajaran PKn terkait nilai-nilai multikultural dalam kurikulum belum tampak atau dimunculkan. Artinya pendidikan kewarganegaraan sangat penting sekali karena selain membangun dan mencerdaskan kehidupan berbangsa juga merupakan bagian dari cita-cita serta tujuan nasional. Pendidikan nasional perlu mencari upaya pembenahan dan penilaian ulang terhadap tujuan pendidikan, kurikulum, proses pendidikan, serta restrukturisasi manajemen pendidikan (Tilaar, 2004, p. 5). Untuk itu, lembaga pendidikan perlu mencari pijakan baru atau basis pengelolaan pendidikan yang lebih relevan dalam konteks kehidupan yang lebih demokratis dan humanistik agar kualitas pendidikan dapat terjamin. Maka dari itu, disayangkan jika bangsa yang besar tidak melakukan perubahan besar-besaran terutama pada bidang pendidikan terutama pelajaran PKn selain mempelajari warga negara demokratis dan warga negara aktif, juga sebagai wahana mengembangkan khasanah keilmuan yang mengedepankan aspek-aspek nilai-nilai multikultural. Peran serta seluruh elemen sangat diperlukan bukan hanya yang bergerak pada bidang pendidikan, namun kebijakan nasional dan situasi kondisi. Masyarkat Indonesia juga sangat menentukan keberhasilan proses pendidikan tersebut terutama penanaman nilai-nilai multikultural dalam pembelajaran PKn.

Samsuri dan Mukhamad (2014, pp. 1-2) mengungkapkan bahwa Madrasah Aliyah merupakan lembaga sebagai salah satu jenjang pendidikan menengah atas dengan kekhasan keagamaan Islam merupakan bagian tidak terpisahkan dalam sistem pendidikan nasional di Indonesia. KeIndonesiaan dan keIslaman tersaji dengan baik selama ini dalam model pendidikan nasional di Madrasah Aliyah. Dalam sistem pendidikan, MA harus bisa memberi warna tersendiri membentuk warga negara global yang memuat nilai-nilai multikultural. Akan tetapi, kenyataanya masih banyak guru serta peserta didik di MA masih belum siap dengan globalisasi dan multikulturalisame. Salah satu sekolah populer (Madrasah Aliyah) yang ada di Yogayakarta adalah Ali Maksum Krapyak, merupakan dari sekian model dan sistem pendidikan berbasis pesantren. Dengan pola pendidikan mencampurkan modern dan tradisonal masih bertahan sampai sekarang menjadi pedoman kebijakan pendidikan MA Ali Makusum. Setiap peserta didik wajib muqim (tinggal) di pesantren. Model pembelajarnnya terintegrasi dengan pesantren 24 Jam. Lulusan Ali Maksum juga telah melahirkan ulama, cendekiawan, tokoh masyarakat, tokoh politik baik ditingkat regional maupun nasional. Keberhasilan peserta didik/santri MA Ali Maksum terbukti dengan banyaknya lulusan yang diterima di Universitas-universitas terpandang baik di luar negeri maupun dalam negeri.

Implementasi nilai-nilai multikultural dalam pembelajaran PKn di MA Ali Maksum perlu adanya peningkatan secara maksimal. Oleh karena itu, Pelaksanaan mengajar selama ini guru kurang kreatif dalam menerapkan inovasi pembelajaran PKn. Hal ini terjadi karena pola pikir belajar diartikan sebagai memperoleh pengetahuan dan pengajaran adalah memindahkan pengetahuan kepada peserta didik. Oleh sebab itu, pembelajaran ditekankan pada hasil, bukan pada proses. 
Akibatnya guru terpaksa mengajar dengan sistem konvensional dengan penggunaan metode ceramah sehingga peserta didik jenuh, tidur saat pelajaran sehingga menghambat proses terkait internalisasi nilai multikultur (prasurvei, 25 Desember 2015).

Mata pelajaran PKn merupakan salah satu mata pelajaran yang memiliki peranan strategis dan penting dalam membentuk sifat dan sikap multikultur peserta didik, diharapkan setiap individu mampu menjadi pribadi yang baik. PKn menuntut peserta didik menunjukkan sikap yang baik, kreatif, dan bertanggung jawab. Namun, kenyataan di lapangan menunjukkan bahwa tujuan pembelajaran PKn belum tercapai sebagaimana yang diharapkan. Melainkan masih perlu dorongan dari pihak lain guna mendukung penerapan implementasi nilai-nilai multikultural. Hal yang tampak nyata dalam berperilaku kurang menghargai dan menghormati serta toleran, misal membuat gaduh pada saat proses pembelajaran, sering terlambat masuk kelas baik pada jam pertama maupun setelah istirahat. Kalau jam kosong pulang ke pesantren (Asrama). Hal ini menunjukkan bahwa perilaku multikultur peserta didik masih labil dan perlu ada penananman nilai multikultur yaitu nilai toleransi, demokrsi, menghormati keadilan dan menghargai (Prasurvei, 28 Desember 2015). Peserta didik MA Ali Maksum terdiri dari berbagai macam daerah yang ada Indonesia dari sabang sampai merauke, bahkan dari tingkatan sosial kemasyarakatan yang berbeda. MA Ali Maksum tidak membedabedakan dalam setiap menerima peserta didik, di mata guru maupun karyawan semua sama, para peserta didik/santri datang untuk mencari ilmu. Hal ini menunjukan bahwa penanaman nilai multikultural dalam pembelajaran PKn sebenarnya sudah terjalin dan terlaksana dengan baik di Madrasah Ali Maksum tersebut.

Banyak peserta didik (santri) dari berbagai daerah serta latar belakang yang beragam yang dimiliki, memberikan nuansa berbeda dari MA Aliyah lainnya. namun karakteristik madrasah tersebut belum diketahui oleh Sekolah (Madrasah) lain yang kemungkinan ingin mengadopsinya. Bahkan, kualitas dan output dari pendidikan di MA Ali Maksum tidak kalah bersaing dengan lainya. MA Ali Maksum ternyata memiliki keunikan tersendiri, Sampai sekarang terus berkembang dengan pesat. Implementasi nilai-nilai multikultural dalam pembelajaran PKn di sekolah (Madrasah) merupakan bagian dari hakekat kehidupan berbangsa dan bernegara dan merupakan salah satu respon terhadap kemajemukan, nilai multikultural dan plural. Oleh karena itu, implementasi nilai-nilai multikultural dalam pembelajaran PKn di MA Ali Maksum Krapyak Yogyakarta adalah sebuah judul yang tepat mewakili penelitian Penulis. Harapannya penulis ini menyajikan hasil akhir yang menggambarkan secara jelas bagaimana MA Ali Maksum menerapkan nilai-nilai multikultural dalam pembelajaran Pendidikan Kewarganegaraan.

\section{METODE}

Jenis Penelitian

Jenis penelitian yang digunakan dalam penelitian ini deskriptif dengan pendekatan kualitatif. penelitian kualitatif adalah proses penelitian dengan menyelidiki masalah sosial. Peneliti membuat gambaran kompleks yang bersifat holistik, menganalisis kata-kata, melaporkan pandanganpandangan para informan secara rinci, dan melakukan penelitian dalam situasi alamiah. Penelitian kualitatif sebagai bentuk penelitian yang mengharuskan menemukan suatu makna sebagai hasil dari eksplorasi terhadap data, kemudian data yang terkumpul dianalisis secara komprehensif dan mendalam dengan melibatkan informan atau partisipan sebagai sumber informasi (Creswell, 2013, p. 4). Penelitian kualitatif bersifat induktif dimana peneliti membiarkan permasalahan-permasalahan muncul dari data atau dibiarkan terbuka untuk diinterpretasi. Data dihimpun dengan pengamatan seksama, mencakup deskripsi dalam konteks yang mendetail disertai catatan-catatan yang lengkap mendukung data yang diperoleh. Dalam mengumpulkan data peneliti menggunakan metode observasi (pengamatan), wawancara, dan dokumentasi.

\section{Lokasi dan Waktu Penelitian}

Penelitian ini dilaksanakan di MA Ali Maksum Yogyakarta Alasan di pilihnya tempat penelitian tersebut, karena memiliki program unggulan yaitu pembelajaran terintegrasi dengan kurikulum pesantren melalui akhlaqul karimah dan nilai toleransi, nilai keadilan, nilai kesetaraan 
melalui berbagai kegiatan sekolah dan pesantren terintegrasi pembelajaran 24 jam. Selain itu, nilai multikultur yang ditanamkan begitu bagus. Tidak adanya sistem perbedaan sesama peserta didik/santri. Kemudian pemilihan pada jenjang MA, dikarenakan pada usia tersebut merupakan masa peralihan psikologis ke arah kematangan dan menunjukkan jati diri. MA Ali Maksum juga berkembang pesat dan menjadi model pembelajaran bagi sekolah lain.

Penelitian diawalai dengan kegiatan observasi pada bulan Agustus-September 2015.

Subyek dan Obyek Penelitian

Subjek penelitian terdiri atas kepala sekolah, waka kurikulum dan pengajaran, waka kesiswaan, guru mata pelajaran PKn, staf dan peserta didik di MA Ali Maksum Yogyakarta. Objek penelitian pada penelitian ini sebagai berikut 1) bagaimana implementasi 2) faktor-faktor implemetasi dan 3) hambatan-hambatan implementasi nilai-nilai multikultural dalam pembelajaran Pendidikan Kewarganegaraan.

\section{Keabsahan Data}

Untuk data yang dapat dipertanggungjawabkan secara ilmiah, perlu dilakukan pemeriksaan keabsahan data. Teknik yang digunakan dalam pemeriksaan data adalah teknik triangulasi. Teknik triangulasi diartikan sebagai teknik pengumpulan data yang bersifat menggabungkan dari berbagai teknik pengumpulan data dan sumber data yang telah ada (Sugiyono, 2013, p. 327). Teknik triangulasi yang digunakan dalam penelitian ini adalah teknik triangulasi dengan memanfaatkan sumber dan metode yaitu teknik pemeriksaan dan keabsahan data yang membandingkan data hasil pengamatan dengan hasil wawancara dan dokumentasi serta dengan pengecekan penemuan hasil dengan teknik pengumpulan data.

\section{Analisis Data}

Teknik analisis data yang digunakan dalam penelitian ini adalah teknik analisis data induktif, yang merupakan penarikan kesimpulan dari fakta-fakta yang khusus, untuk kemudian ditarik kesimpulan secara umum (generalisasi). Adapun langkah-langkah analisis data dalam penelitian ini adalah reduksi data, kategorisasi dan unitisasi data, display data, dan pengambilan kesimpulan, sebagaimana dikemukakan oleh Miles dan Huberman (1984), mengemukakan bahwa aktivitas dalam analisis data, yaitu: data reduction, data display, and data conclusion drawing verification.

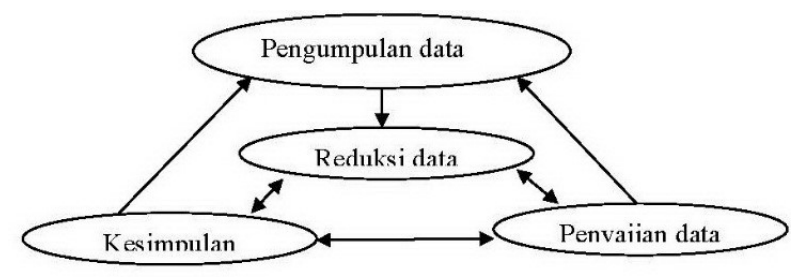

Gambar 1. Gambar. 1 Alur Analisis Penelitiaan

Sumber: Skema analisis interaksi dari Miles dan Huberman (1984, p. 23).

Kultur sekolah diyakini memiliki peran dalam menghasilkan produktivitas kerja yang baik pada masing-masing individu dan unit kerja sekolah. Oleh karena itu, sekolah sebagai satu institusi pendidikan, perlu membangun konektivitas yang bersinergi dengan antarwarga sekolah dengan cara positif agar memperbaiki kualitas sekolah yang bersangkutan. Beberapa kajian menunjukkan salah satu faktor penghambat pencapaian prestasi sekolah dan pembentukan karakter siswa ialah kultur 
atau budaya sekolah. Oleh karena itu, untuk memperbaiki kualitas sekolah perlu dilakukan melalui sentuhan budaya sekolah terlebih dahulu jika mutu pendidikan ingin diperbaiki. Pada penelitian ini, sesuai dengan data yang ditemukan bahwa karakter disiplin siswa dapat dibentuk melalui kultur sekolah yang teridentifikasi melalui artifak sekolah, tata tertib, ritus atau upacara-upacara yang rutin dilaksanakan di sekolah, dan nilai-nilai atau keyakinan yang dianut oleh warga sekolah. Untuk lebih jelas dapat dilihat pada Tabel 1 .

\section{HASIL DAN PEMBAHASAN}

Impelementasi nilai-nilai multikultural dalam pembelajaran PKn di MA Ali Maksum Krapyak meliputi dua tataran implementasi yaitu konseptual dan operasional. Konseptual dari rumusan visi, misi, tujuan dan kurikulum madrasah sedangkan operasional meliputi kegiatan perencanaan, pelaksanaan dan evaluasi pembelajaran.

Implemetasi nilai-nilai multikultural dalam Pembelajaran PKn

\section{Tataran Konseptual}

Nilai-nilai multikultural tertuang pada visi MA Ali Maksum Krapyak yakni, berilmu, beradab, dan berprestasi. Arti berilmu adalah mampu memahami semua cabang ilmu baik agama dan umum. Beradab menjadikan peserta didik/santri berakhlakul karimah. Berprestasi maksudnya adalah harapannya peserta didik mampu mengembangkan segala potensi untuk berkreasi dan berprestasi. Dalam hal ini penanaman nilai-nilai tersebut muncul ketika sebuah ilmu itu dipelajari, kemudian beradab adalah dengan perilaku mulia, hormat-mengormati, toleransi, demokrasi dan tolong menolong. sedangkan berprestasi adalah sebuah pencapaian keberhasilan dari suatu hasil usaha keras dalam proses belajar mengajar sehingga tercipta prestasi baik akaedmik/nonakademik. Memiliki visi dalam menjawab tantangan perkembangan zaman serta peningkatan sumber daya manusia, baik kuantitas maupun kualitas internal maupun eksternal. Dan peningkatan pelayanan masyarakat, menjadikan MA Ali Maksum menjadi pilihan bagi orang tua santri/peserta didik untuk menuntut ilmu. Tujuan pendidikan di MA Ali Maksum selalu mengaitkan dengan nilai-nilai kehidupan berbangsa dan bernegara, sosial dan keragaman (Multikultural) yang tercantum maupun yang tertuang dari para pendapat serta dari pemikiran pendiri.

Kurikulum berbasis pesantren menjadi bagian terpenting penyelenggaraan pendidikan multikultural di MA Ali Maksum. Dengan keterbukaan, kesederajatan dan keadilan serta saling menghormati. Kurikulum berbasis pesantren menanamkan nilai toleransi, demokrasi, menghormati dan tolong-menolong tanpa memandang dan melihat dari latar belakang yang berbeda. Kurikulum semacam ini merupakan prinsip MA Ali Maksum Krapyak yang mungkin perlu diadopsi oleh sekolah-sekolah lain terutama berbasis pesantren. Nilai-nilai kehidupan berbangsa dan bernegara salah satunya adalah menjunjung tinggi demokrasi, kesetaraan, keadilan dan toleransi. Dengan demikian, dalam visi dan misi MA Ali Maksum mengandung nilai-nilai multikultural. Hal ini sesuai dengan teori yang dikemukakan oleh Demir dan Yurdakul (2015, p. 3652) bahwa pendidikan multikultural ditangani sebagai ide atau gerakan pendidikan oleh siswa untuk mencapai keberhasilan akademik dan gerakan reformasi yang mengubah semua elemen penting pendidikan, termasuk nilainilai yang mendasari, aturan prosedural, kurikulum, bahan ajar, struktur organisasi dan kebijakan pemerintahan untuk mencerminkan pluralisme budaya. Berdasarkan hasil wawancara, observasi dan dokumentasi analisis nilai-nilai multikultural secara konseptual sesuai dengan konsep pendiri dan teori terkait nilai-nilai multikultural.

Tataran Operasional

Perencanaan pembelajaran

Kegiatan perencanaan pembelajaran yang dilakukan di MA Ali Maksum Krapyak Yogyakarta meliputi penyusunan silabus dan pengembangan RPP. Terdapat komponen pembelajaran dalam silabus dan RPP yakni tujuan, materi, metode media dan evaluasi. Kelima komponen tersebut 
digunakan dalam mengembangkan RPP. Silabus dan RPP pada kurikulum nasional baik K-13 maupun KTSP mencakup tiga ranah yakni afektif, kognitif dan psikomotorik, selanjutnya tujuan afektif sudah terdapat pada tujuan multikultural, namun hanya berupa toleransi, rasa hormat, perhatian dan demokratis. Sedangkan tujuan untuk bertoleransi dan menghargai belum tercantumkan dengan jelas. Pertama, Tujuan pembelajaran multikultural secara eksplisit mengarah pada ranah kognitif, afektif dan psikomotorik yang membentuk kesadaran multikultural. Ranah kognitif yang dirumuskan juga sudah terdapat tujuan mengenai pengetahuan wawasan keragaman walaupun belum semuanya peserta didik mencerminkan wawasan keragaman. Afektif bertujuan dapat menerima keragaman dan perbedaan yang ditandai dengan bertoleransi, menghargai dan menghormati keragaman. Sedangkan tujuan psikomotorik secara implisit telah mendukung tujuan kognitif dan psikomotorik secara implisit telah mendukung tujuan kognitif dan afektif seperti gerakan-gerakan peserta didik dalam sikap multkultural. Hal ini sesuai Teori yang dikemukakan oleh Parekh (2008, p. 299) mengemukakan tujuan pendidikan adalah mempertahankan identitas budaya dan etnis para murid, memupuk perasaan bangga atas sejarah dan keberhasilan mereka serta membantu menciptakan komunitas etnis yang kohesif.

Kedua, Materi yang diajarkan hendaknya bernilai kultural dan mengandung wawasan keragaman. Materi yang dipilih dapat didasarkan pada kebutuhan dan karakteristik yang beragam serta terdapat peristiwa dan permasalahan sosial yang terjadi dengan menggunakan persitiwa nyata, berita terkini, isu-isu wawasan nasional dan global, permasalahan yang sedang terjadi dan yang terdapat di sekeliling lingkungan peserta didik. Berdasarkan hasil yang tertera pada silabus terdapat materi yang berhubungan dengan keragaman yaitu menelusuri dinamika perekembangan demokrasi di Indonesia, disini kompetensi dasarnya adalah menghayati persamaan kedudukan warga negara tanpa membedakan ras, agama dan kepercayaan, gender, golongan, budaya, dan suku dalam kehidupan bermasyarakat, berbangsa, dan bernegara. Ketiga, Metode yang dipilih adalah demokratis yang menghargai perbedaan dan keragaman. Pemilihan metode tersebut didasarkan pada karakteristik peserta didik yang beragam. Guru dapat memahami gaya belajar peserta didiknya untuk menentukan metode yang bervariasi. Metode yang dipilih guru PKn MA Ali Maksum Krapyak berdasarkan dinamika peserta didik, santai dan tidak menekan peserta didik. Metode tercantum dalam RPP dan silabus telah bervariasi. Dalam RPP, metode pembelajaran lebih bervariasi dari pada yang tercantum dalam silabus.

Keempat, Media merupakan alat bantu dalam menyampaikan materi sehingga peserta didik diharapkan lebih mudah memahami dan mendalami materi. Media yang dipilih juga telah bervariasi. Namun sejatinnya media yang dipilih tersebut belum menggunakan contoh-contoh media yang berhubungan dengan keragaman terkait isu-isu multikultural. Hal ini sesuai teori yang dikemukakan oleh Banks dan Banks $(2019$, p. 27) the instructional materials, bahan ajar merupakan komponen penting dalam proses pembelajaran. Dengan demikian bahan ajar termasuk media membangun nilai multikultur, karena dengan media bisa mempermudah dan memperlancar akses pembelajaran. Kelima, Evaluasi merupakan cara untuk melihat keberhasilan peserta didik dalam belajar. Evaluasi peserta didik dapat dilihat dari seluruh aspek kognitif dengan membuat dan mengerjakan soal, serta afektif bisa dilihat dari sikap peserta didik yang selanjutnya dimasukan dalam rapor narasi (K-13). Psikomotorik dilihat dari ujian kompetensi. Namun dalam menilai sikap peserta didik yang dapat menghargai nilai demokrasi, nilai toleransi, nilai menghargai sesama, nilai keadilan dan persamaan belum ditemukan teknik evaluasi khusus dalam menilai sikap multikultural peserta didik tersebut.

Penilaian tersebut memberikan kesetaraan bagi peserta didik. Dalam penilaian pada ranah afektif, kognitif, dan psikomotorik selalu mengacu pada aturan perangkat pembelajaran, jadi disesuaikan. (Print \& Lange, 2012, p. 59) mengemukakan bahwa berbagai macam bentuk evaluasi yaitu dengan banyak model, sampel sekolah tidak cukup untuk dapat memberikan analisis yang kuat keberhasilan mereka. Artinya bentuk evaluasi harus bisa menyesuaikan berdasarkan model/strategi karakteristik peserta didik masing-masing. Banks dan Banks (2019, p. 27) dalam teorinnya asessment and testing procedurs, penilaian dan dasar pengujian adalah untuk mengkur keberhasilan mencapai tujuan multikultur. Salah satu bentuknya adalah melalui tahapan evaluasi. Dengan demikian, MA Ali Maksum dalam pembelajaran PKn sudah memuat nilai-nilai multikultural. Hal ini, dibuktikan dari hasil wawancara dengan Guru PKn dan observasi serta dokumen-dokumen perangkat pembelajaran. 
Pelaksanaan Pembelajaran

Menanamkan nilai untuk bersikap toleransi, menghargai, demokrasi, keadilan, kesetaraan dan menghormati keragaman

Penanaman dan menumbuhkan sikap pada nilai-nilai multikultural tersebut dilakukan melalui keteladanan, nasehat dan contoh. Guru senantiasa memberikan pembiasaan serta keteladanan kemudian nasehat-nasehat dan diberikan contoh-contoh peristiwa terkait keragaman dalam menanamkan nilai-nilai multikultural. Contoh-contoh merupakan hal yang sederhana dalam penanaman nilai nila tersebut. Dilworth $(2008$, p. 4) mengatakan kompetensi kewarganegaraan multikultural meliputi keterampilan komunikasi pribadi dan antar budaya, pengetahuan tentang sistem budaya, sosial, dan politik; dan kemampuan untuk secara kritis berpikir tentang kehidupan sipil dan politik yang terjadi diantara kelompok-kelompok yang beragam. Putnam (1993, pp. 90-91) mengatakan bahwa ciri-ciri masyarakat kewargaan salah satunya adalah Solidarity, trust, tolerance tampak dalam perilaku saling membantu, saling memiliki, mempunyai kepercayaan penuh satu dengan lainnya meskipun memiliki pandangan berbeda, tetapi tetap toleran. Rice dan Sumberg (1997, p. 99) mengkategorikan element of a civic culture kedalam 4 kategori, yaitu: 1.) Civic engagement; 2.) Political equality; 3.) Solidarity, trust, and tolerance; dan 4.) Social structures of cooperation. Dalam budaya masyarakat, yaitu sikap masyarakat dalam berpartisipasi dalam urusan publik dan mempromosikan kepentingan publik. Dari uraian di atas menunjukan bahwa nilai-nilai multikultural tercermin dari nilai keadilan persamaan, toleransi, menghargai, hormat menghormati dan kearifan lokal.

Metode yang demokratis, kooperatif dan bervariasi.

Metode yang digunakan telah bervariasi, demokratis dan kooperatif. Dengan metode demokratis diharapkan peserta didik dapat memahami nilai-nilai multikultural. Hal tersebut dibuktikan bahwa guru menggunakan metode yang bervariasi, berpusat pada peserta didik dan santai seperti metode kartu mix method dan game. Guru juga memberikan kebebasan gaya belajar peserta didik. Metode meningkatkan kerjasama, saling menghargai, saling menghormati, demokratis. Metode ini diharapkan mampu meningkatkan pemahaman dan menghayati arti pentingnya nilai-nilai multikultural. Sekolah memberikan kebebasan dan menghargai bagi peserta didiknya dalam belajar, sehingga peserta didik dapat mengembangkan kemampuannya tanpa tekanan, dapat berpikir secara bebas. Hal ini sesuai dengan teori (Print \& Lange, 2012, p. 118) yaitu Class discussions of social and moral issue, Simulations \& Games, In class debats, Service learning. Sedangkan menurut teori dari Banks dan Banks (2019, p. 15) Prejudice reduction, yaitu mengidentifikasi karakteristik ras siswa dan menentukan metode pengajaran mereka. Kemudian, melatih kelompok untuk berpartisipasi dalam kegiatan olahraga, berinteraksi dengan seluruh staff dan siswa yang berbeda etnis dan ras dalam upaya menciptakan budaya akademik yang toleran dan inklusif. Sedangkan teori dari Birzea (2010) dalam proyek education for democratic citizenship, collaberative learning adalah situasi dimana terdapat dua atau lebih orang belajar atau berusaha untuk belajar sesuatu secara bersama-sama (Birzea, 2000, p. 26).

\section{Materi yang diajarkan mengandung wawasan keragaman, persitiwa dan masalah sosial}

Materi dalam pembelajaran PKn telah mengambil contoh permasalahan dan persitiwa politik, ekonomi, keamanan, hukum dan sosial yang terdapat pada tataran global. Guru juga menyampaiakn wawasan keragaman kepada peserta didik. Materi yang disampaikan mengambil kasus-kasus yang sedang terjadi artinya terkini berdasarkan berita terbaru, dan menggunakan contohcontoh lingkungan masyarakat sekitar. Jadi materi PKn yang diberikan nanti disusupi tentang nilainilai toleran maupun hormat menghormati dan saling memahami satu sama lain. Pembelajaran juga harus menyampaikan wawasan keragaman. Berdasarkan hasil wawancara dengan peserta didik madrasah aliyah Ali Maksum dapat diporoleh bahwa guru menggunakan sumber belajar dengan memanfaatkan lingkungan masyarakat dan fenomena sosial masyarakat yang terjadi dilingkungan sekitar. Guru juga memasukkan contoh-contoh wawasan kebangsaan, wawasan keragaman etnis, budaya, suku, ras, agama, bahasa. 
Teori ini sesuai yang dikemukakan oleh Banks dan Banks (2019, p. 15) content integration, yaitu mengintegrasikan berbagai budaya dan kelompok untuk mengilustrasikan konsep dasar, generalisasi, dan teori dalam mata pelajaran/disiplin ilmu. Dapat disimpulkan bahwa guru memasukkan contoh-contoh wawasan kebangsaan, wawasan keragaman etnis, budaya, suku, ras, agama, bahasa dan peristiwa serta masalah sosial. Hal ini sesuai dengan teori dari Banks dan Banks $(2019$, p. 27) teaching styles and strategies, ialah suatu model pengajaran dan strategi yang dilakukan oleh guru agar tercipta suasana pembelajaran demokratis, keadilan, kesetaraan, toleran, dan menghargai.

\section{Melatih peserta didik untuk memecahkan masalah-masalah sosial}

Guru melatih peserta didik untuk memecahkan masalah sosial yang terjadi sehingga peserta didik mampu mebuat keputusan serta bersikap multikultur dan toleran berkaitan dengan konsep, isu, maupaun persoalan yang dihadapinya yang langsung berhubungan dengan keragaman. Cara guru dalam melatih peserta didik untuk memecahkan masalah-masalah sosial adalah dengan pendekatan Study kasus, diskusi dan pemecahan masalah (problem solving). Print dan Lange (2012, p. 118) dengan Problem based learning pemecahan masalah peserta didik akan sangat aktif dan kreatif dan demokratis. Seluruh guru PKn telah memberikan kesempatan yang sama terhadap peserta didik, memberikan bantuan dan perhatian, interaksi guru dan peserta didik terbuka dan komunikatif, menegur peserta didik jika salah dan memberikan pujian jika benar. Kedua guru PKn melatih peserta didik dalam memecahkan masalah sosial melalui studi kasus, diskusi, debat dan pemecahan masalah (problem solving). Sani (2014, p. 127) mengemukakan pembelajaran berbasis masalah ini merupakan model pembelajaran yang penyampaiannya dilakukan dengan cara menyajikan suatu permasalahan, mengajukan pertanyaan, memfasilitasi penyelidikan dan membuka dialog. Teori dari Zulaeha (2013, p. 508) syntagmatic multicultural model-based investigation group, yaitu sintagmatik multikultural model berbasis investigasi, yaitu pemecahan masalah adalah hal yang sederhana dalam menanamkan sikap multikultur. Keragaman dalam masyarakat pesantren terutama di MA Ali Maksum menyangkut tentang bahasa, budaya, etnisitas, dan sebagainya, adalah sebuah fakta yang tidak dapat diingkari.

\section{Media Pembelajaran}

Media yang digunakan guru PKn Madrasah Aliyah Ali Maksum Krapyak belum beragam masih terbatas pada papan tulis (whiteboard), LCD dan Laptop. Guru di MA juga belum menggunakan media yang berhubungan dengan keragaman. Hal tersebut dikarenakan penggunaan media yang berhubungan dengan keragaman disesuaikan dengan materi yang disampaikan. Media yang digunakan tersebut melibatkan seluruh peserta didik namun akan lebih baik jika bervariasi dan menggunakan media yang berhubungan dengan keragman disebabkan karena minimnya media yang disediakan madrasah yang berhubungan dengan keragaman. Jika ingin menunjukkan media yang berhubungan dengan keragaman, guru mengajak peserta didik ke ruang perpustakaan atau ruang komputer untuk mengakses internet, laboratorium komputer disana akan mengakses segala materi termasuk materi yang mempunyai muatan multikultural. Berdasarkan hasil wawancara, dokumentasi dan observasi guru PKn di MA Ali Maksum dalam memberikan materi melalui media pembelajaran yang aktif, kreatif dan bervariasi. Media inilah guru melatih dan menanamkan nilai-nilai multikultural seperti nilai toleransi, demokrasi dan keadilan akan tercapai dan terlaksana dengan baik.

\section{Evaluasi Pembelajaran}

Evaluasi pembelajaran berbasis multikultural meliputi keseluruhan kemampuan dan kepribadian peserta didik yang dilihat dari persepsi, pemahaman, apresiasi, tindakan dan sikap peserta didik yang dapat menghargai keragaman dan perbedaan. Teknik evaluasi yang digunakan sebaiknya beragam seperti menggunakan tes lisan, tes perbuatan dan tes tertulis, wawancara, observasi, pengukuran sikap dan penilaian hasil karya (portofolio). Evaluasi yang digunakan guru MA Ali Maksum Krapyak dalam menilai ranah kognitif sudah bervariasi. Namun untuk menilai ranah afektif khususnya sikap multikultural peserta didik belum bervariasi. Guru hanya menggunakan teknik hafalan saja dalam menilai sikap afektif peserta didik dan belum menggunakan 
instrumen penilaian afektif. Evaluasi ranah psikomotorik dilihat dari ujian kompetensi yang dilaksanakan saat UTS dan UAS. Peserta didik juga telah memiliki wawasan keragaman, dapat menghormati, menghargai, persaudaraan dan bertoleransi terhadap keragaman.

Peserta didik adalah warga negara yang sedang dalam proses, karena masih harus dididik menjadi warga negara dewasa yang sadar akan hak dan kewajibannya. Oleh karena itu, masyarakat sangat mendambakan generasi mudanya dipersiapkan untuk menjadi warganegara yang baik dan dapat berpartisipasi dalam kehidupan masyarakat dan negaranya. Branson (1999, p. 4) menjelaskan tiga komponen penting dalam pendidikan kewarganegaraan, yaitu civic knowledge (pengetahuan kewarganegraan), civic skills (keterampilan kewarganegraan), dan civic disposition (watak-watak kewarganegraan). Setiap generasi khususnya peserta didik harus memperoleh pengetahuan, mempelajari keahlian, dan mengembangkan karakter pribadi dan publik yang sejalan dengan demokrasi konstitusi. Sikap mental ini harus dipelihara dan dipupuk melalui perkataan dan pengajaran serta kekuatan keteladanan. Berdasarkan hasil wawancara, observasi dan dokumentasi bahwa implementasi nilai-nilai multikultural dalam pembelaran PKn mengandung keragaman, yaitu nilai-nilai multkultural sebagai berikut: 1.) Nilai hidup dengan orang lain, hidup dengan orang lain yang tercermin dalam kehidpuan sehari-hari. Ini diekspresikan dalam dua hal; pertama kultur yang beragam dan kitab kuning (MA basis Pesantren); 2.) Persamaan dan keadilan, setiap siswa memiliki hak yang sama tanpa membedakan latar belakang yang berbeda; 3.) Persaudaraan dan tolong menolong, dilandasi oleh persamaan nasib, tujuan belajar, nilai-nilai ini juga dibangun melalui metode pembelajaran; 4.) Demokrasi dapat dicermati dari aspek pengajaran, metode, serta kegiatan di Madrasah; 5.) Toleransi dan saling menghargai, visi lembaga dan kegiatan madrasah seperti pemecahan masalah; dan 6.) Kerjasama, kerjasama dengan berbagai pihak berupa program terbangun dengan baik, titik kerjasama meliputi dukungan dalam prinsip demokrasi, HAM, toleransi beragama, gender, dan sebagainya.

Faktor-faktor pendukung implementasi nilai-nilai multikultural dalam pembelajaran PKn di MA Ali Maksum Krapyak meliputi.

\section{Peran kepala Sekolah}

Kepala Sekolah merupakan pucuk kepemimpinan, menjadi seorang pemimpin berarti siap menjadi contoh dan teladan. Kepala sekolah harus menjadi panutan baik dalam hal kepribadian maupun unjuk kerja. Kualifikasi pribadi berupa serangkaian sifat yang harus dimiliki oleh setiap pimpinan pada umumnya termasuk kepala sekolah menjadi pengembangan kultur yang di terapkan di sekolah. peran kepala sekolah sangat besar sekali. Selain sebagai pemimpin dan pengontrol sekolah (Madrasah). Kepala sekolah selalu memberikan kesan dan pesan tentang arti pentingnya nilai-nilai Multikultural. Melalui pendidikan multikultural, peserta didik yang berasal dari ras, etnis, budaya, agama, bahasa, kelas sosial ekonomi dan jenis kelamin yang berbeda mendapat kesempatan yang setara dan adil untuk mengenyam pendidikan di sekolah dalam pembelajaran. Hal ini sesuai dengan teori yang dikemukakan oleh Banks dan Banks (2019, p. 27) school policy and politics dengan demikian kepala sekolah merupakan pemegang kebijakan dan politk dalam sekolah dukungan terkait nilai multikultural. Dengan demikian peran kepala sekolah sangat penting sekali dalam mendukung penerapan nilai-nilai multikultural di Madrasah.

\section{Peran Guru}

Guru PKn sangat berperan dalam implementasi nilia-nilai multikultural, peran guru dapat diwujudkan mendidik dan membimbing serta membina hubungan harmonis dengan warga sekolah, misalnya dengan membina hubungan harmonis dengan guru dan karyawan dapat diwujudkan dengan silaturohmi ke rumah guru dan karyawan. Sedangkan keakraban dengan peserta didik dapat dimulai dengan kultur salaman, bertegur sapa, sharing, dan kegiatan-kegiatan lainnya yang ada di madrasah aliyah Ali Maksum. guru-guru yang ada di MA Ali Maksum sudah seperti keluarga, hal ini tidak ada jarak antara guru satu dan yang lainnya, kultur pesantren jelas memberikan nuansa yang berbeda dengan yang lainnya. Guru harus mengerti dan mempunyai pemahaman yang multikultur, humanis, dialogis-persuasif, kontekstual dan aktif sosial, termasuk didalamnya keberagaman yang inklusif. Apabila guru memiliki paradigma tersebut, maka ia akan mengajarkan dan mentransfer nilai-nilai 
tersebut kepada peserta didik. Dari hasil penelitan yang dilakukan, setidaknya ada dua peran guru dalam mengembangkan nilai-nilai multikultural. Pertama, wawasan dan pemahaman guru tentang multikulturalisme, kedua, proses pembelajaran yang dilakukan guru. Berdasarkan hasil wawancara, observasi dan dokumentasi guru PKn sangat berperan sekali terutama dalam penanaman nilai-nilai multikultural. Hal ini, berdasarkan observasi ketika guru memberikan pelajaran dikelas guru selalu menanamkan nilai-nilai keragaman. Baik itu, toleransi, keadilan, kesetaraan dan demokrasi.

\section{Kurikulum Sekolah}

Pada umumnya kurikulum yang dipakai oleh sekolah-sekolah mengacu pada kurikulum nasional saja, tetapi di MA Ali Maksum kurikulmnya berbasis pesantren. kurikulum nasional yang dipakai adalah untuk kelas X adalah K-13 sedangkan kelas XI-XII adalah KTSP. Bagaimanpun kurikulum berwawasan multikultural sudah kental terasa dalam setiap mata pelajaran yang ada terutama muatan kepesantrenan. Berbicara MA Ali Maksum terkait pendidikan multikultural sudah menjadi bagian dari pembelajarannya walaupun belum secara tertulis, tetapi diinternalisasikan nilainilai multkultural tersebut. Hal ini sesuai dengan teori dari Banks dan Banks (2019, p. 27) yaitu: 1.) The school culture and hidden curriculum; dan 2.) The formulazied curriculum and course of study yang kemudian di perkuat oleh pendapat Raihani (2012, pp. 590-591) yang menyatakan bahwa kurikulum multikultural harus bersifat terbuka dan bisa berkembang sesuai dengan kebutuhan. Dan juga dilakuakan dengan dialog, hal ini akan mempermudah aspek pedagogi dalam pendidikan multikultural bagi warga sekolah.

\section{Media belajar}

Sarana dan prasarana media dan alat belajar sangat penting sekali dalam mewujudak penanaman nilai-nilai multikultural. Hal ini dapat dipahami bersama, tanpa adanya dukungan media maupun alat belajar akan menjadi hambatan yang cukup serius dalam proses pembelajaran multkilultural sehingga dalam proses belajar mengajar berhasil. Pentingnya laboratorium dan perpustakaan menjadikan siswa bisa berekspresi dan berkreasi berdasarkan kompetensi yang dimilikinnya sehingga alat maupun media belajar merupakan sarana pendukung dalam pendidikan multikultural. Contoh sikap dan keteladanan tergambarkan dalam buku-buku tentang kasus intoleran, media yang mendukung dengan bersama-sama dalam pembelajaran seperti mengkaji kasus-kasus kekerasan agama, kasus-kasus intoleran, percaturan politik. Semua merupakan salah satu fasilitas sekolah untuk mendukung pendidikan multikultural dalam pembelajaran di MA Ali Maksum Krapyak. Berdasarkan hasil wawancara, observasi dan dokumentasi ditemukan bahwa guru dalam proses pembelajaran PKn terkait nilai-nilai multikultural adalah dengan adanya media pembelajaran kreatif, inovatif dan aktif. Media pembelajaran merupakan salah satu sarana pembelajaran PKn yang nantinya peserta didik diberikan pemahaman dan penanaman nilai keragaman seperti nilai demokrasi, toleransi, menghargai dan keadilan.

\section{Kegiatan dan program sekolah}

MA Ali Maksum memiliki kegiatan sekolah dan program sekolah yang dapat memfasilitasi peserta didiknya yang beragam. Kegiatannya sekolah biasannya diisi dengan lomba-lomba. Program sekolah yang dibuat juga telah memfasilitasi berbakat dan berprestasi. Salah satu kegiatan adalah lomba-lomba yang diadakan baik tingkat sekolah, kabupaten, maupun propinsi, dengan memberikan kesempatan lomba memberikan perhatian, pelayanan, memberikan kebutuhan yang setara dan menghargai setiap individu dengan mengadakan lomba karena dapat mengapresiasikan peserta didik dapat tampil dan berkespresi. Sekolah menyediakan banyak lahan untuk eksistensi para peserta didik. Berdasarkan hasil wawancara, observasi dan dokumentasi bahwa proses pembelajaran PKn terkait nilai-nilai multikultural juga didukung oleh kegiatan dan program sekolah yang mengedepankan dan menanamkan nilai keragaman, sehingga peserta didik tidak dalam proses penanaman nilai multikultral dalam pembelajaran PKn tidak hanya dengan kognitif dan afektif tetapi melalui psikomotorik sehingga internalisasi nilai toleransi, keadilan, demokrasi, menghargai, kesetaraan dapat langsung dipraktikan.

\section{Iklim Sekolah}


Iklim sekolah di MA Ali Maksum Krapyak telah mencerminkan suasana muultikultural. Antara peserta didik dapat bergaul, bermain bersama, tidak memilih-milih teman. Interaksi peserta didik dengan guru juga dekat. Sekolah mengajarkan peserta didik untuk saling menghargai, menghormati, dan bertoleransi. Selain peserta didik, guru dan karyawan sekilas juga diberikan sosialisasi untuk saling menghargai, menghormati, dan bertoleransi. MA Ali Maksum Krapyak iklimnya begitu multikultural, hal ini diperkuat dengan suasana Krapyak menjadi kampung santri, menjadikan Krapyak mempunyai Iklim yang ramah, saling menghormati, menghargai, dan toleran. Suasana MA berbasis pesantren membawa dampak peserta didik/santri hidup seperti saudara dan kekeluargaan seperti tolong menolong. Hal ini dapat diketahui dari hasil wawancara, Betapa rukun dan saling tolong menolong antar sesama tidak membeda-bedakan temannya dari latar belakang baik etnis, suku, dan budaya. Madrasah berbasis pesantren mendidik dan menjadi ciri khas tersendiri karena berdasarkan faktor lingkungan iklim sekolah/pesantren inilah mendorong peserta didik menanamkan nilai-nilai multkultural tersebut dengan pembiasaan.

\section{Peserta didik/santri}

Keragaman yang terdapat pada peserta didik bukan menjadi hambatan karena peserta didik sudah terbiasa menghargai dengan teman yang berbeda dari peserta didik tersebut. Keragaman tersebut dapat dimanfaatkan dalam menanamkan sikap toleransi, menghargai, menghormati, terhadap perbedaan dan keragaman serta dijadikan sebagai sumber belajar. Peserta didik yang dilihat dari latar belakang dan sifat peserta didik dapat menjadi faktor pendukung pembelajaran. Peserta didik juga berpengaruh dalam penerapan pendidikan multikultural karena peserta didik adalah subjek dari penerapan tersebut. Dengan banyaknya peserta didik MA Ali Maksum yang beragam semakin bagus, karena semakin banyak untuk dijadikan bahan penanaman nilai multkultural dalam pembelajaran. Lingkungan maupun iklim pesantren juga sangat berpengaruh sekali terhadap penanaman nilai-nilai multikultural. Salah satunya diungkapkan oleh Bapak Hilmy bahwa peserta didik berasal dari seluruh indonesia

Hal ini, sesuai teori yang dikemukakan oleh Branson (1999, p. 4) menjelaskan terdapat tiga komponen penting dalam pendidikan kewarganegaraan, yaitu civic knowledge (pengetahuan kewarganegraan), civic skills (keterampilan kewarganegraan), dan civic disposition (watak-watak kewarganegraan). Sementara pengajar berperan sebagai fasilitator atau mitra belajar peserta didik dalam seluruh proses pembelajaran dikelas. Sejalan dengan paradigma ini, materi pembelajaran pendidikan kewargaan disusun berdasarkan pada kebutuhan mendasar dan universal warga negara yang semakin kritis dan saling terkait sama dengan yang lainnya. Berdasarkan hasil wawancara, observasi dan dokumentasi bahwa faktor pendukung implementasi nilai-nilai multikultural dalam pembelajaran PKn di MA Ali Maksum Krapyak Yogyakarta adalah peran kepala sekolah, peran guru, kurikulum sekolah, media pembelajaran, kegiatan dan program sekolah, iklim sekolah dan santri.

Hambatan-hambatan Implementasi Nilai-nilai Multikultural dalam Pembelajaran PKn

\section{Kesiapan dan kesadaran peserta didik}

Guru adalah fakor utama yang paling penting dalam mengimplementasikan nilai-nilai keragaman yang inklusif dan toleran. Dalam konteks pendidikan madrasah aliyah yang berbasis pesantren yang terintegrasi selama 24 jam, menuntut kesiapan dan kesadaran siswa yang luar biasa, hal ini agar siswa mampu memahami dan menerima segala perbedaan setiap individu dengan yang lainnya agar nantinya memiliki karakter yang kuat, untuk selalu bersikap toleran, demokratis, humanis, dan religious. Karena dengan pemahaman yang kurang mendalam kurang berdampak baik terhadap perkembangan dan pemahaman peserta didik. Hal lain yang perlu dibenahi bersama juga kesadaran peserta didik. Dengan kesadaran dan kesiapan peserta didik maka pembelajaran akan berjalan dengan lancar tanpa adannya hambatan. Hambatan yang terjadi pada pembelajaran terutama Pkn yang bermuatan nilai-nilai multikultural diharapkan dapat mampu terselesaikan dengan baik. Berdasarkan hasil wawancara, observasi dan dokumentasi ditemukan bahwa kesadaran dan kesiapan peserta didik menjadi hambatan (tantangan) dalam pembelajaran PKn terkait nilai-nilai multikultural. 


\section{Sarana dan Prasarana}

Sarana dan prasaran merupakan faktor terpenting dalam pelaksanaan pembelajaran. Selain dapat mampu membantu dan menopang serta memfasilitasi kegiatan pembelajaran, sarana dan prasarana juga menjadi cerminan sebuat alat untuk mencapai tujuan. MA Ali Maksum juga mempunyai keterbatasan, dengan banyaknya pendaftar dari berbagai penjuru Indonesia mereka semua belomba-lomba masuk ke madrasah aliyah Ali Maksum. Kekurangannya seperti keterbatasan seperti ruang kelas, gedung, dan lain sebagainnya. Alat pembelajaran juga belum lengkap semua, terbukti ketika pembelajaran dengan presentasi kadang guru PKn mengalami kesusahan diakibatkan LCD yang terbatas dan ruang yang terbatas, dan akibatnya sering bergantian sehingga proses belajar mengajar kurang maksimal. Jadi hambatan dalam penanaman nilai multkultural adalah dengan keterbatasan sarana dan prasarana. Berdasarkan hasil wawancara, observasi dan dokumentasi sarana dan prasarana yang terbatas menjadi hambatan terkait pelaksanaan nilai-nilai multikultural dalam pembelajaran PKn.

\section{Minimnya ruang untuk melakukan Refleksi}

Tinggal di asarama merupakan ciri khas nyantri di pondok pesantren dan bersekolah. Salah satunya adalah madrasah aliyah Ali Maksum, mereka tinggal di asrama dengan peraturan yang cukup ketat, karena peraturan tersebut mengacu pada yayasan. Refleksi diri dalam ruang outdoor merupakan salah satu strategi yang baik, terutama terkait dengan refleksi diri. Dengan keterbatasan ruang indoor, atau kegiatan-kegiatan outbond akan sangat mempengaruhi bentuk refleksi anak. Outbond atau kunjungan di MA Ali Maksum begitu jarang sekali, minimnya kegiatan untuk berefleksi mengakibatkan kejenuhan dan keterbatasan dalam berekspresi, berkreasi, kegiatankegiatan semacam ini masih jarang dilaksanakan setiap setahunnya. Salah satu hambatan dalam penanaman nilai-nilai multkultural adalah minimnya ruang untuk berefleksi. Selain itu berdasarkan observasi di Madrasah Aliyah Ali Maksum Krapyak masih ditemukan hambatan yaitu: 1.) Tidak semua materi PKn mengandung keragaman, walaupun mata pelajaran PKn mempelajari tentang warga negara demokratis, Undang-Undang, dan kehidupan bangsa dan negara, namun tidak semua materi PKn mengkaji keragaman; 2.) Minimnya media tentang keragaman. Madrasah 'Aliyah Ali Maksum belum memiliki banyak media yang berhubungan dengan keragaman seperti gambar; 4.) Minimnya papan-papan maupun tulisan tentang keragaman; 5.) Kedisiplinan anak atau peserta didik dalam mengikuti kegiatan pembelajaran PKn banyak yang tidur dan kadang tidak masuk. Berdasarkan hasil wawancara, observasi dan dokumentasi ditemukan bahwa proses internalisasi nilai-nilai multikultural dalam pembelajaran PKn di MA Ali Maksum Krapyak yogyakarta meliputi kesadaran dan kesiapan peserta didik, sarana dan prasaran serta minimnya runag untuk melakukan refleksi

\section{SIMPULAN}

Berdasarkan hasil penelitian yang telah dilaksanakan di MA Ali Maksum Krapyak Yogyakarta mengenai implementasi nilai-nilai multikultural dalam pembelajaran PKn dapat disimpulkan sebagai berikut: 1.) Implementasi nilai-nilai multikultural dalam pembelajaran PKn meliputi dua tataran implementasi yaitu konseptual dan operasional. Konseptual dari rumusan visi, misi, tujuan dan kurikulum madrasah sedangkan operasional meliputi kegiatan perencanaan, pelaksanaan dan evaluasi pembelajaran. Tataran Konseptual Nilai-nilai multikultural tertuang pada visi MA yakni, berilmu, beradab, dan berprestasi. Arti berilmu adalah mampu memahami semua cabang ilmu baik agama dan umum. Beradab menjadikan peserta didik/santri berakhlakul karimah. Berprestasi maksudnya adalah harapannya peserta didik mampu mengembangkan segala potensi untuk berkreasi dan berprestasi. Misi, mempersiapkan alumni berkiprah di masyarakat yang memiliki visi dalam menjawab tantangan perkembangan zaman serta peningkatan sumber daya manusia, baik kuantitas maupun kualitas internal maupun eksternal. Tujuan pendidikan selalu mengaitkan dengan nilai-nilai kehidupan berbangsa dan bernegara, sosial dan keragaman (Multikultural) yang tercantum maupun yang tertuang dari para pendapat serta dari pemikiran pendiri. 
Tataran operasional kegiatan perencanaan pembelajaran yang dilakukan di MA meliputi penyusunan silabus dan pengembangan RPP. Terdapat komponen pembelajaran dalam silabus dan RPP yakni tujuan, materi, metode media dan evaluasi. Kelima komponen tersebut digunakan dalam mengembangkan RPP. Pelaksanaan pembelajaran PKn terkait nilai multikultural dalam proses pembelajaran yaitu pertama menanamkan nilai untuk bersikap toleransi, menghargai, demokrasi, keadilan, kesetaraan dan menghormati keragaman melalui keteladanan, nasehat dan contoh; 2.) Metode yang demokratis, kooperatif dan bervariasi melalui diskusi, ceramah dan studi kasus; 3.) Materi yang diajarkan mengandung wawasan keragaman, persitiwa dan masalah sosial melalui contoh permasalahan dan persitiwa politik, ekonomi, keamanan, hukum dan sosial; 4.) Melatih peserta didik untuk memecahkan masalah-masalah sosial melalui studi kasus dan problem solving; dan 5.) Media pembelajaran dengan media yang bervariasi. dan evaluasi pembelajaran.

Faktor-faktor pendukung meliputi: 1.) Peran kepala sekolah, kepala sekolah merupakan pucuk kepemimpinan, menjadi seorang pemimpin berarti siap menjadi contoh dan teladan; 2.) Peran guru, sangat berperan dalam implementasi nilia-nilai multikultural, peran guru dapat diwujudkan mendidik dan membimbing serta membina hubungan harmonis dengan warga sekolah; 3.) Kurikulum sekolah, kurikulum yang dipakai di madrasah aliyah Ali Maksum menggunakan kurikulum berbasis pesantren; 4.) Media belajar, merupakan media dan alat belajar penting sekali dalam mewujudkan penanaman nilai-nilai multikultural; 5.) Kegiatan dan program seperti baksos dan ekstrakurikuler yang menjadikan peserta didik dapat memahami arti pentingnya toleransi; 6.$)$ Iklim sekolah yang multikultural; dan 7.) Peserta didik atau santri sebagai subjek dari pendidikan multikultural. Hambatan-hambatan sebagai berikut: 1.) Kesiapan dan kesadaran peserta didik, kesiapan dan kesadaran yang masih rendah dalam proses internalisasi nilai multikultural; 2.) Sarana dan prasaran yang belum lengkap menjadi tantangan bagi guru dan peserta didik dalam penanaman nilai multikultural; dan 3.) Minimnya ruang untuk refleksi, minimnya ruang refleksi mengakibatkan kejenuhan dan keterbatasan dalam berekspresi, dan berkreasi.

\section{DAFTAR PUSTAKA}

Adha, M, M. \& Yanzi, H. (2013). Model pengembangan pembelajaran pendidikan kewarganegraan berbasis multikultur dalam rangka menanamkan nilai-nilai HAM dan demokrasi. Media Komunikasi FIS, 12(2). doi:http://dx.doi.org/10.23887/mkfis.v12i2.1705

Banks, J. A., \& Banks, C. A. M. (Eds.). (2019). Multicultural education: Issues and perspectives. Washington: John Wiley \& Sons.

Birzea, C. (2000). Education for democratic citizenship: A lifelong learning perspectives. Council for Cultural Co-operation, CDCC.

Branson, S. M. (1999). Belajar civic education dari Amerika. Yogyakarta : LkiS.

Mahfud, C. (2014). Pendidikan multikultural. Yogyakarta: Pustaka Pelajar.

Creswell, J. (2013). Research design qualitative, quantitative, and mixed approaches. California: Sage Publications.

Demir, N. \& Yurdakul, B. (2015). The examination of the required multicultural education characteristics in curriculum design. Procedia-Social and Behavioral Sciences, 174, 36513655. doi:https://doi.org/10.1016/j.sbspro.2015.01.1085

Dilworth, P. P. (2008). Multicultural citizenship education. In Arthur J., Davies, I., \& Hahn, C. L. (Eds.), The SAGE handbook of education for citizenship and democracy (pp. 424-437). London: SAGE

Tilaar, H.AR. (2004). Multikulturalisme, tantangan global masa depan. Jakarta: Grasindo

Miles, M. B., \& Huberman, A. M,. (1984). An expanded sourcebook : Qualitative data analylis. (2ed ed). London : SAGE Publications. 
Parekh, B. (2008). Rethinhking multiculturalism: Keragaman budaya dan teori politik. Kanisius: Yogyakarta.

Print, M. \& Lange, D. (2012). Schools curriculum and civic education for building democratic citizens. Rotterdam: sense publishers.

Putnam, R. D. (1993). Making democracy work: Civic tradition in modern Italy. Princeton, New Jersey: Princeton University Press.

Raihani, R. (2012). Report on multicultural education in pesantren. Compare: A Journal of Comparative and International Education, 42(2), 585-605. doi:https://doi.org/10.1080/03057925.2012.672255

Rice, T. M., \& Sumberg, A. F. (1997). Civic culture and government performance in the American States. Publius: The Journal of Federalism, 27(1), 99-114. doi:https://doi.org/10.1093/oxfordjournals.pubjof.a029899

Sani, R. A. (2014). Pembelajaran saintifik untuk implementasi kurikulum 2013. Jakarta: Bumi Aksara.

Samsuri, S., \& Mukhamad, M. (2014). Pembinaan karakter kewargaan multikultural berbasis pilarpilar kebangsaan di Madrasah Aliyah se-Daerah Istimewa Yogyakarta. Laporan penelitian tahunan hibah bersaing Universitas Negeri Yogyakarta: Tidak diterbtkan.

Sugiyono, S., (2013). Metode penelitian pendidikan, pendekatan kuantitatif, kualitatif, dan R\&D. Bandung: Alfabeta.

Zamroni, Z.. (2001). Pendidikan untuk demokrasi: Tantangan menuju civil society. Yogyakarta: Bigraf Publishing.

Zulaeha, I. (2013). Innovation models of Indonesian learning in multicultural society. ProcediaSocial and Behavioral Sciences, 103, 506-514. doi:https://doi.org/10.1016/j.sbspro.2013.10.367 